\title{
Effective Biosorptive Elimination of Fluoride and Sulfide Ions from Water Using Chemical Modified Rice Bran in Economical Way
}

\author{
AMARA DAR ${ }^{1}$, RABIA REHMAN ${ }^{*}$, PARSA DAR ${ }^{2}$, AYESHA KAUSAR ${ }^{3}$, SABA NOREEN $^{4}$, \\ LIVIU MITU ${ }^{5 *}$ \\ ${ }^{1}$ Institute of Chemistry, University of the Punjab, Lahore-54590, Pakistan \\ ${ }^{2}$ University of Macau, Taipa, Macau, China \\ ${ }^{3}$ Shanghai Jiao Tong University, Shanghai, China \\ ${ }^{4}$ University of the Chinese Academy of Sciences Beijing, Beijing, China \\ ${ }^{5}$ University of Pitesti, Department of Nature Sciences Pitesti, 1 Targu din Vale Str., 110040, Pitesti, Romania
}

\begin{abstract}
Due to industrial development the sulfide ions are present in excess in the effluents from tanneries, whereas ceramic and glass industries are the major contributors of fluoride ions. The concentration of these ions is beyond permissible limit in water bodies, thereby causing serious health issues. An attempt is made to highlight the effectiveness of chemical modification of rice bran with zinc chloride for the removal of sulfide and fluoride ions from aqueous solutions. Batch mode adsorption study was conducted. Mechanism of adsorption was explored by applying the isothermal models like Langmuir and Freundlich. Maximum adsorption capacity $(\mathrm{mg} / \mathrm{g})$ revealed that zinc chloride modification of rice bran increased the sulfide and fluoride removal from $3.79 \mathrm{mg} / \mathrm{g}$ to $7.08 \mathrm{mg} / \mathrm{g}$ and $1.37 \mathrm{mg} / \mathrm{g}$ to $2.06 \mathrm{mg} / \mathrm{g}$, respectively. Sulfide ions were more efficiently eliminated using the selected adsorbent in its modified form.
\end{abstract}

Keywords: Sulfide, Fluoride, Biosorption, Rice bran, Freundlich and Langmuir isotherms.

\section{Introduction}

To meet the requirements of increasing population, our industrial sector has been developing with same pace. Industries are producing waste in both liquid and solid forms. The pollution in our aquatic environment is a big concern because the pollutants in form of metal ions are directly or indirectly threatening to environment and human life [1]. As the conventional treatment methods are not cost effective and low-cost treatment methods and technologies are unable to remove wishful amount of pollutants so, industrial waste water released directly into drain or nearby land devoid of any pretreatment.

Fluoride as an essential part of drinking water is constructive in making our teeth and bones healthy, while intake of fluoride in excess may inflames skeletal fluorosis, which results in bone deformities [2]. Besides of water, which is being used for drinking purpose, fluoride can also enter our body through industrial exposure. The waste water of fertilizer [3], ceramics [4], glass [5], steel production industry [6] and the plants that are incinerate municipal waste [7] are the major source of fluoride pollution in aquatic environment.

Sulfide $\left(\mathrm{S}^{2-}\right)$, a divalent anion of sulfur, is present in ground water because of sulfide ores. Sulfide ions either in form of $\mathrm{H}_{2} \mathrm{~S}$ exposure or other water-soluble sulfide salts are very harmful to our body [8]. Nowadays many industries like pulp paper manufacturers, petrochemical and the most important tanneries (to transforms animal hide into leather) are using sulfide species [9]. So, tanneries and other industrial effluents are considered as main anthropogenic sources that hold a bulk amount of sulfide ions.

*email: grinorganic@yahoo.com; ktm7ro@yahoo.com; 
There were various technologies and scientific methods that had been practiced removing these toxic species from water [10]. To control the concentration of fluoride in aquatic environment scientists have used reverse osmosis, coagulation, electrocoagulation [11], precipitation [12], nanofiltration [13], electro-dialytic membrane technologies [14, 15]

and adsorption [16] using various materials [17]. On the other hand, sulfide concentration on a large scale can be controlled by the process of aeration and by using chemical oxidants [18] like $\mathrm{Cl}_{2}$, $\mathrm{KMnO}_{4}, \mathrm{H}_{2} \mathrm{O}_{2}, \mathrm{ClO}^{-}, \mathrm{O}_{2}$, manganese (IV)-oxide $\left(\mathrm{MnO}_{2}\right)$ [10, 19]. Surrounded by the aforesaid technologies and methods, biosorption is more effective one for controlling the alarming concentration of fluoride and sulfide in aquatic environment, mainly in waste water of industries. For adsorption of various toxic metals and ions, plant wastes are very important candidate from last few decades [20]. As plant waste is inexpensive, freely available, and has good and selective adsorption capacity for various pollutants [21, 22]. The process of adsorption solely depends on ions of choice (adsorbate) [23] which diffuse to the superficial surface of adsorbent, where weak intermolecular forces incorporate to hold adsorbate with adsorbent [24]. By chemical treatment of plant waste or by employing various modifying agents (base solution of sodium hydroxide) $[25,26]$; the biosorption capacity can be enhanced to remove sulfide and fluoride species [27]. Rice bran, a hard-outer layer and byproduct of rice (Oryza sativa L.) has been used in present study. Rice is an Asian crop with $90 \%$ production and intake in this expanse. With Pakistan reference, this country is 5th largest exporter and at $11^{\text {th }}$ in world rice production so, rice bran is easily available when brown rice travels through the whiteners and polishers. In our present study, we have used the conventional method of adsorption because of its various practiced characteristics like selectivity, suitability, regenerability and compatibility with our lab facilities. Rice bran has been used as an adsorbent (phyto-filter) besides of its nutritional benefits (cereals, rich source of vitamin $\mathrm{B}_{6}$, phosphorus, iron, potassium, magnesium and thiamin) for the treatment of waste water.

\section{Materials and methods}

\subsection{Reagents}

All chemicals consumed in this work were of analytical grade. Stock solutions of fluoride and sulfide were prepared by dissolving a calculated amount of sodium fluoride (Sigma Aldrich) and sodium sulfide (Sigma Aldrich) in double distilled water to make the desired concentrations. For fluoride estimation $0.1 \mathrm{M} \mathrm{HCl}$ and $\mathrm{NaOH}$ solutions were used to adjust the $p \mathrm{H}$ of solution. For sulfide estimation $0.1 \%$ of 1,10-phenanthroline and $0.01 \mathrm{M}$ of Ferric chloride solutions were used. Acetate buffer was employed for controlling $p \mathrm{H}$ of solution.

\subsection{Biosorbent}

Rice bran (RB) was collected from a Rice Processing Mill, District Gujranwala, Punjab, Pakistan. Later, it was meshed to remove any foreign particles or impurities. One part of this raw rice bran (RRB) was used as such, whereas, remaining part was soaked in $0.1 \mathrm{M} \mathrm{ZnCl}_{2}$ for 45 minutes and the resulting mixture was filtered, washed with distilled water, dried in oven for $24 \mathrm{~h}$ at $85^{\circ} \mathrm{C} . \mathrm{ZnCl}_{2}$ modified biosorbents were already reported to be used for removal of nitrate [28], sulphate [29], molybdate [30], thiocyanate ions [31, 32] and heavy metals [33, 34]. That's why this chemical treatment mode was selected. Later, this chemical treated rice bran (CRB) was ground into fine powder.

\subsection{Biosorption conditions optimization experiments}

A series of experiments were performed with $50 \mathrm{~mL}$ solution of $10 \mathrm{ppm}$ sodium fluoride and 50 $\mathrm{mL}$ solution of sodium sulfide $(20 \mathrm{mg} / \mathrm{L})$ solutions in batch mode, to optimize various parameters. Effects of various parameters on biosorption capacity was studied by varying biosorbent (RB and CRB) dose from 0.2-2.0 g, contact time 5-70 minutes, shaking speed 50-450 rpm, adsorbate concentration 2-14 ppm at room temperature $(273 \mathrm{~K})$. The effect of $\mathrm{pH}$ was studied in range of 3-9. 


\section{Equipment and Apparatus}

The concentration of fluoride and sulfide in aqueous solutions was monitored spectrophotometrically using HITACHI U1800 spectrophotometer at $510 \mathrm{~nm}$. FT-IR spectra were recorded in range of $4000 \mathrm{~cm}^{-1}$ to $500 \mathrm{~cm}^{-1}$ using Thermo Nicolet iS10 Spectrometer.

\subsection{Theoretical Analysis}

It is important to determine the type of adsorption using various isotherm models. Various parameters of adsorption system are optimized by validating the experimental data. In this present work, experimental data were validated by using two well-known adsorption isotherm models. Adsorption isotherms determine the equilibrium associated between adsorbate and adsorbent.

Freundlich isotherm model is represented by logarithmic dependence at equilibrium of $\mathrm{q}_{\mathrm{e}}$ (amount of adsorbate at equilibrium) on $\mathrm{C}_{\mathrm{e}}$ (concentration of solution), equation (1):

$$
\log q_{e}=\log K_{F}+\frac{1}{n} \log C_{e}
$$

where " $\mathrm{K}_{\mathrm{F}}$ " is a adsorption capacity constant of the adsorbent $(\mathrm{mg} / \mathrm{g})$ and $1 / \mathrm{n}$ shows the adsorption intensity.

Langmuir isotherm model is represented by following equation (2):

$$
1 / q_{e}=1 /\left(b q_{m} \mathrm{c}_{e}\right)+1 / q_{m}
$$

where " $\mathrm{C}$ " denotes liquid phase equilibrium concentration $(\mathrm{mg} / \mathrm{L})$, " $\mathrm{q}_{\mathrm{m}}$ " is monolayer adsorption capacity $(\mathrm{mg} / \mathrm{g})$ and " $\mathrm{b}$ " is Langmuir constant $(\mathrm{L} / \mathrm{g})$, linked to the free adsorption energy.

\section{Results and discussions}

Agricultural waste is a lignocellulosic material, used as adsorbent, because it is accessible in large amount and considered as a cheap and renewable material. Hence, a comparative study has been conducted to find the suitability and applicability of rice bran (raw and chemically treated) as ecofriendly adsorbent to remove fluoride and sulfide ions from aqueous solutions.

\subsection{Characterization of (RRB) and (CRB) adsorbents}

\section{(a) FT-IR Analysis}

A comparative study of FT-IR spectra of RRB and CRB has been done to identify various functional groups that act as potential adsorption sites. The recorded FT-IR spectra of raw (RRB), chemical treated rice bran (CRB) is shown in Figures1 and 2, respectively. The recorded peak shifts of RRB are shown in Table 1 [35]. The shifting of band $3287.63 \mathrm{~cm}^{-1}$ (RRB) to $3273.52 \mathrm{~cm}^{-1}$ (PU6) is representing hydroxyl (-OH) stretching. Peak $2918.88 \mathrm{~cm}^{-1}$ (RRB) shifted to $2922.19 \mathrm{~cm}^{-1}$ (PU6) and $2918.91 \mathrm{~cm}^{-1}$ (PU7) is attributing the $-\mathrm{CH}$ stretching vibrations of its hydrogen, both asymmetric and symmetric. The peak $1709.27 \mathrm{~cm}^{-1}$ (RRB) shifted to $1709.43 \mathrm{~cm}^{-1}$ (PU7) is corresponding to $\mathrm{C}=\mathrm{O}$ of aldehyde or carboxylic acid. The shift of peak $1651.63 \mathrm{~cm}^{-1}$ (RRB) to $1650.53 \mathrm{~cm}^{-1}$ (PU6) and 1648.35 $\mathrm{cm}^{-1}$ (PU7) respectively is attributing the aromatic $\mathrm{C}=\mathrm{C}, \mathrm{C}=\mathrm{O}$ and conjugated ketones or $\mathrm{C}=\mathrm{N}$ amide stretching. Peak $1547.95 \mathrm{~cm}^{-1}(\mathrm{RRB})$ is corresponding to symmetrical stretching of aromatic band $\mathrm{C}=\mathrm{O}$ of aldehyde or carboxylic acid which disappeared in (PU6), (PU7). The methyl asymmetric $\mathrm{C}-\mathrm{H}$ bands at peak $1242.15 \mathrm{~cm}^{-1}$ (RRB) which also disappeared after fluoride and sulfide ions adsorbed. Peak $1015.99 \mathrm{~cm}^{-1}$ (RRB) is shifted to $1031.72 \mathrm{~cm}^{-1}$ (PU6) and $1029.27 \mathrm{~cm}^{-1}$ (PU7) is ascribing the CO stretching of alcohol, sulfoxides, carbohydrates or polysaccharide-like substances [36]. 


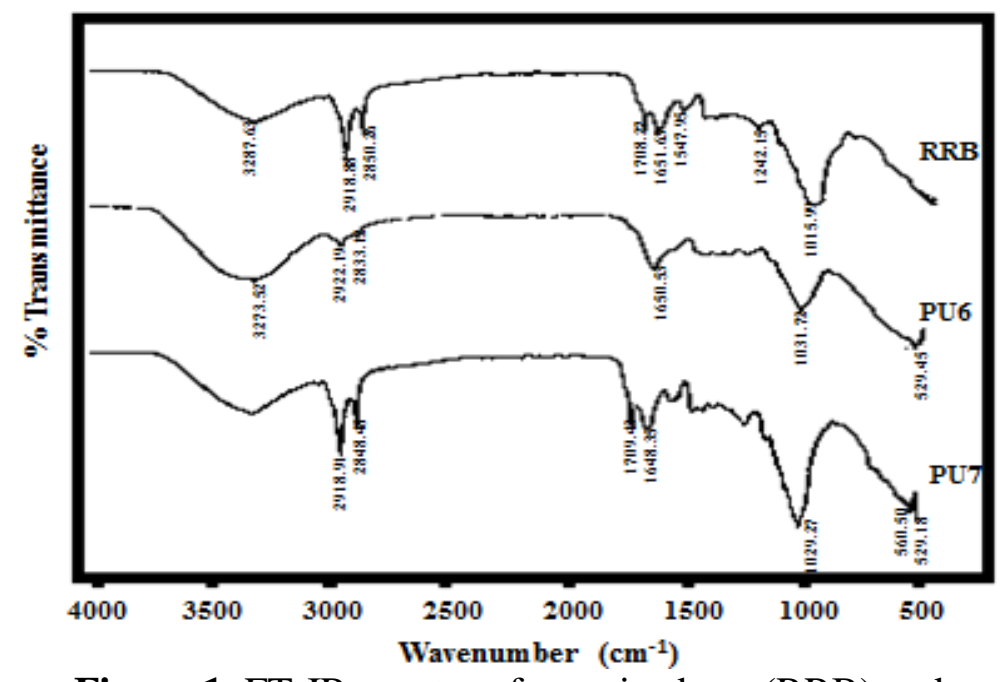

Figure 1. FT-IR spectra of raw rice bran $(\mathrm{RRB})$ and post-adsorption of fluoride and sulfide ions on RRB

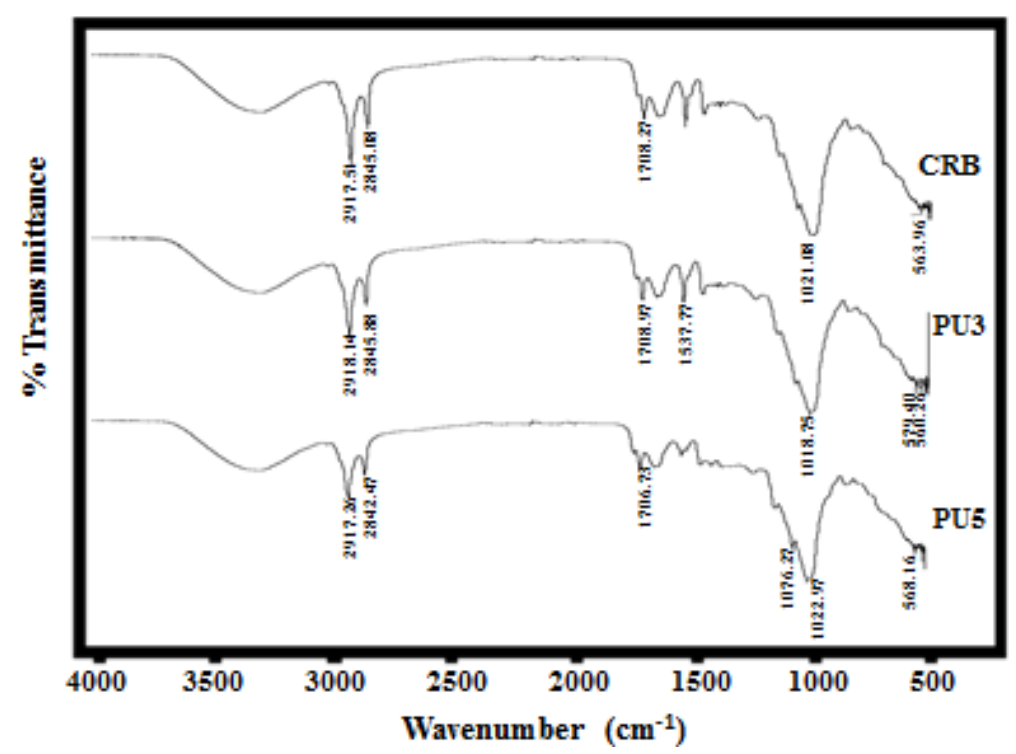

Figure 2. FTI-R spectra of chemical treated rice bran (CRB) and post-adsorption of fluoride and sulfide ions on $\mathrm{CRB}$

Table 1. Comparative ft-ir analysis of raw rice bran (rrb) and Post-adsorption of fluoride and sulfide ions on $\mathrm{rrb}$

\begin{tabular}{|c|c|c|}
\hline \multicolumn{3}{|c|}{ FT-IR ANALYSIS, wavenumber $\left(\mathbf{c m}^{-1}\right)$} \\
\hline RRB (B)* & PU6 (A)* & PU7 (A)* \\
\hline 3387.63 & 3273.52 & - \\
\hline 2918.88 & 2922.19 & 2918.91 \\
\hline 2850.26 & 2833.12 & 2848.48 \\
\hline 1708.28 & - & 1709.43 \\
\hline 1651.63 & 1650.53 & 1648.35 \\
\hline 1547.95 & - & - \\
\hline 1242.15 & - & 1029.27 \\
\hline 1015.99 & * B (Before adsorption), * A (After adsorption) \\
\hline
\end{tabular}


Table 2.Comparative FT-IR analysis of chemical treated rice bran (crb) and post-adsorption of fluoride and sulfide ions ON CRB

\begin{tabular}{|c|c|c|}
\hline \multicolumn{3}{|c|}{ FT-IR ANALYSIS, wavenumber $\mathbf{( c m}^{-\mathbf{1}}$ ) } \\
\hline CRB (* & PU3 (A)* & PU5 (A)* \\
\hline 2917.51 & 2918.14 & 2917.26 \\
\hline 2845.08 & 2845.88 & 2842.47 \\
\hline 1708.27 & 1708.97 & 1706.73 \\
\hline- & 1537.77 & - \\
\hline- & - & 1076.27 \\
\hline 1021.08 & 1018.75 & 1022.97 \\
\hline
\end{tabular}

In case of CRB (Table 2), the shifting of band $2917.51 \mathrm{~cm}^{-1}$ (CRB) to $2918.14 \mathrm{~cm}^{-1}$ (PU3) and $2917.26 \mathrm{~cm}^{-1}$ (PU5) is attributing the $-\mathrm{CH}$ asymmetric and symmetric stretching vibrations of methylene hydrogen. The peak $1708.27 \mathrm{~cm}^{-1}$ (CRB) is shifted to $1708.97 \mathrm{~cm}^{-1}$ (PU3) and $1706.73 \mathrm{~cm}^{-1}$ (PU5) corresponding to $\mathrm{C}=\mathrm{O}$ of aldehyde or carboxylic acid. Emergence of new park $1537.77 \mathrm{~cm}^{-1}$ in PU3 is corresponding to symmetrical stretching of aromatic band $\mathrm{C}=\mathrm{O}$ of aldehyde or carboxylic acid. The new absorption peak of $1076 \mathrm{~cm}^{-1}$ in PU5 and peak $1021.08 \mathrm{~cm}^{-1}$ (CRB) to $1018.75 \mathrm{~cm}^{-1}$ (PU3) and $1022.97 \mathrm{~cm}^{-1}$ (PU5) is ascribing the $\mathrm{C}-\mathrm{O}$ stretching of alcohol, sulfoxides, carbohydrates or polysaccharide-like substances [37].

\section{(b) SEM Analysis}

The morphological changes occurred in rice bran sample before and after biosorption of sulfide and fluoride ions were monitored by scanning electron microscopy (SEM). SEM image of raw rice bran Fig. 3-a showed a gelatinous prickly pear morphology which transformed into mottled surface with micro fluffs after the adsorption of fluoride ions

Figure 3-b, whereas, the prickly pear texture of raw rice bran was filled after the adsorption of sulfide ion, giving an abraded morphology Figure 3-c.

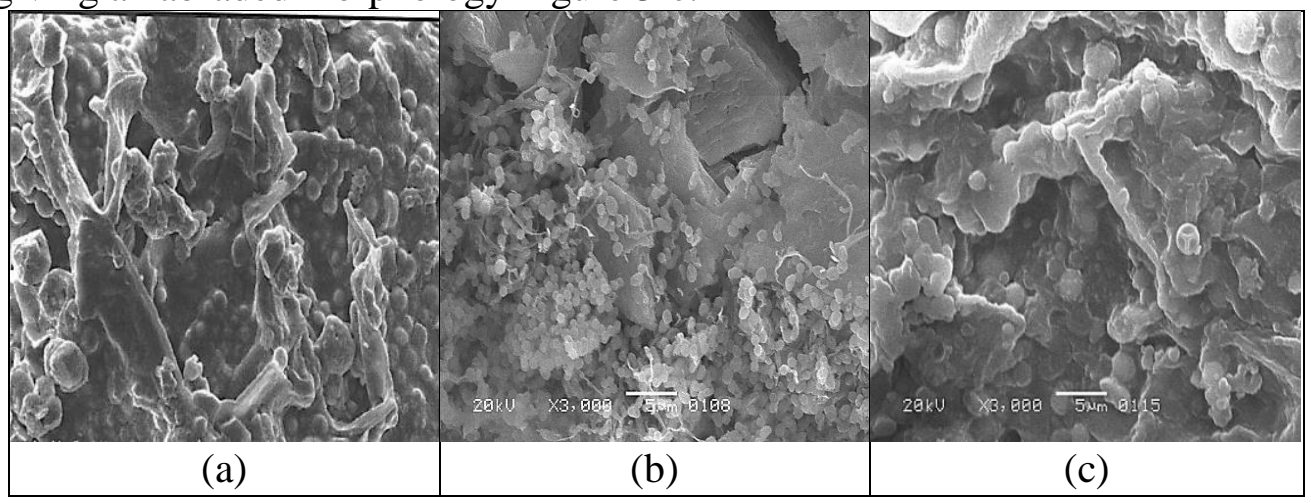

Figure 3. (a) Raw rice bran before adsorption (b) Raw rice bran after the adsorption of $\mathrm{F}^{-}$ions (c) Raw rice bran after the adsorption of $\mathrm{S}^{2-}$ ions

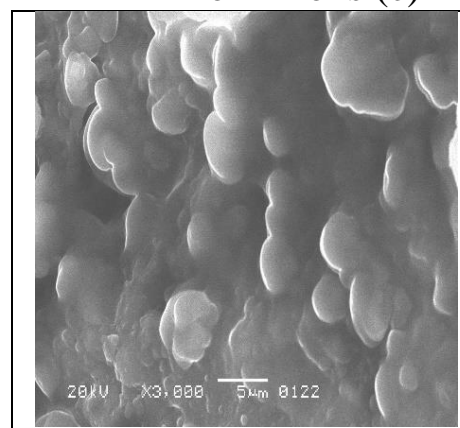

(a)

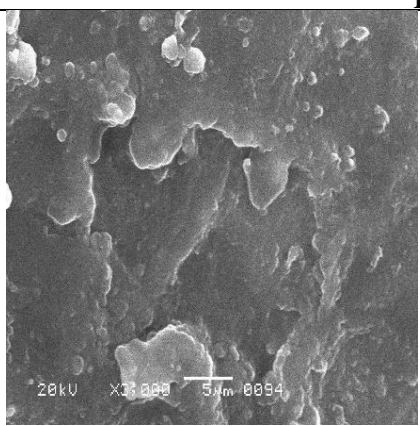

(b)

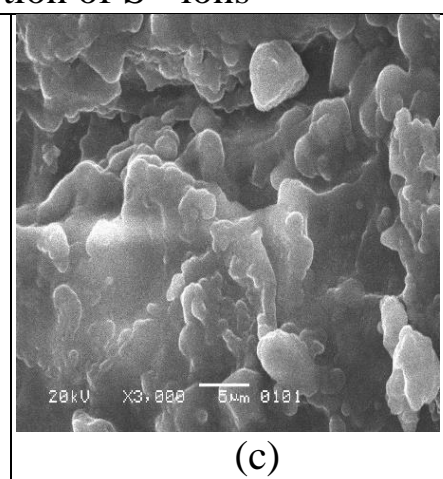

(c)

Figure 4. (a) Chemically treated rice bran (CRB) before adsorption (b) CRB after the adsorption of $\mathrm{F}^{-}$ions (c) $\mathrm{CRB}$ after the adsorption of $\mathrm{S}^{2-}$ ions 
SEM image of chemically treated rice bran showed a gelatinous morphology (Figure 4-a) which transformed into flaked surface after the adsorption fluoride ions (Figure 4-b), whereas, after the adsorption of sulfide ions mottled gel like morphology (Figure 4-c) [38].

\subsection{Study of Adsorption Process Characteristics}

\section{(a) Effect of Adsorbent Dose}

Particularly, the adsorbent dosage is important as it determines the degree of removal and it may be used to calculate the adsorbent cost per unit of aqueous solution to be treated. Generally, the percentage removal efficiency increases with an increase in adsorbent dosage, since more chelating sites are available. The same phenomenon was detected for the biosorption of fluoride and sulfide ions using RRB and CRB, as shown in Figure 5. In case of RRB, maximum biosorption $82.35 \%$ was observed for sulfide removal (SRRB), whereas, in case of CRB, maximum removal efficiency $78.61 \%$ was observed for fluoride removal (FCRB curve). It was evident that biosorption capacity enhanced by increased adsorbent dose because the surface area of adsorbent increases with availability of higher active adsorption sites.

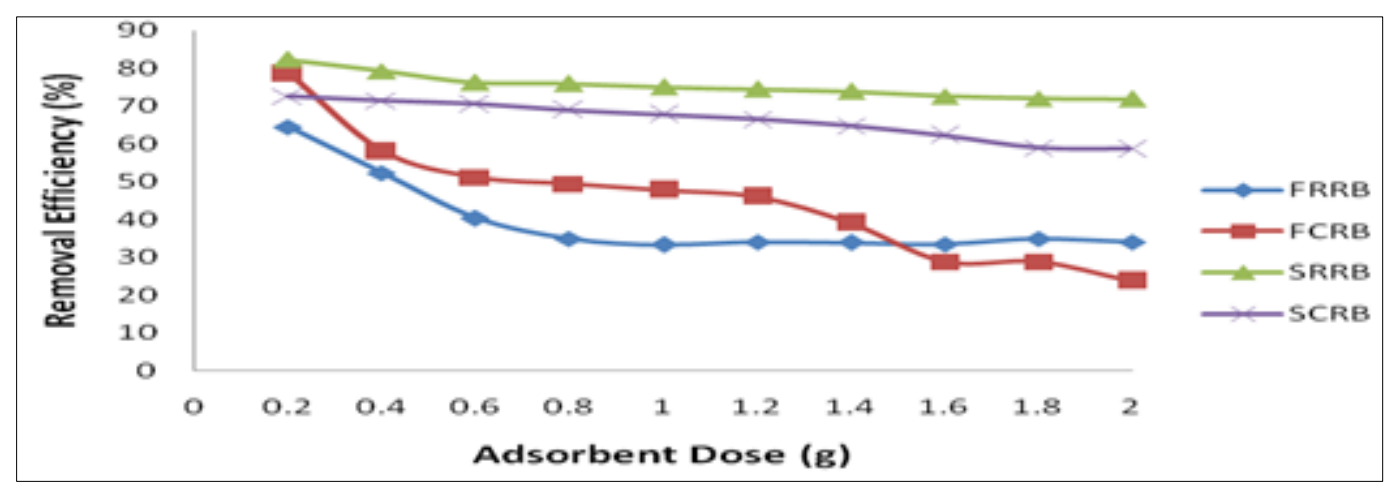

Figure 5. Adsorbent dose effect on biosorptive elimination of fluoride and sulfide ions; $10 \mathrm{ppm}$ fluoride ions, $20 \mathrm{mg} / \mathrm{L}$ sulfide ions, both solutions in $50 \mathrm{~mL}$ volume; RRB, CRB 0.1-2.0 g; time 5-70 min; shaking speed 50-450 rpm; $p \mathrm{H} 3-9$; temperature $293 \mathrm{~K}$

\section{(b) Effect of Contact Time}

For the choice of an adequate adsorbent, contact time is important. The effect of contact time on fluoride and sulfide ions removal is shown in Figure 6. It is evident from the results that CRB was more effective in sulfide ion chelation with maximum biosorption efficiency $82.73 \%$ in $25 \mathrm{~min}$ (SCRB curve), whereas, CRB also showed maximum biosorption at $81.14 \%$ of fluoride ions in 35 min (FCRB curve). There was no noticeable change in biosorptive removal of anions after these optimized contact intervals, because under operating conditions, maximum adsorption took place due to the presence of higher number chelating site on biosorbent surface. Generally, the adsorbate molecules covered adsorbent surface progressively and after some time block the whole surface. When it occurs, the adsorbent unable to adsorb any more adsorbate molecules, which reflects that the adsorption capacity rises with time and reaches a constant value of time after which no considerable increase is removal efficiency observed. 


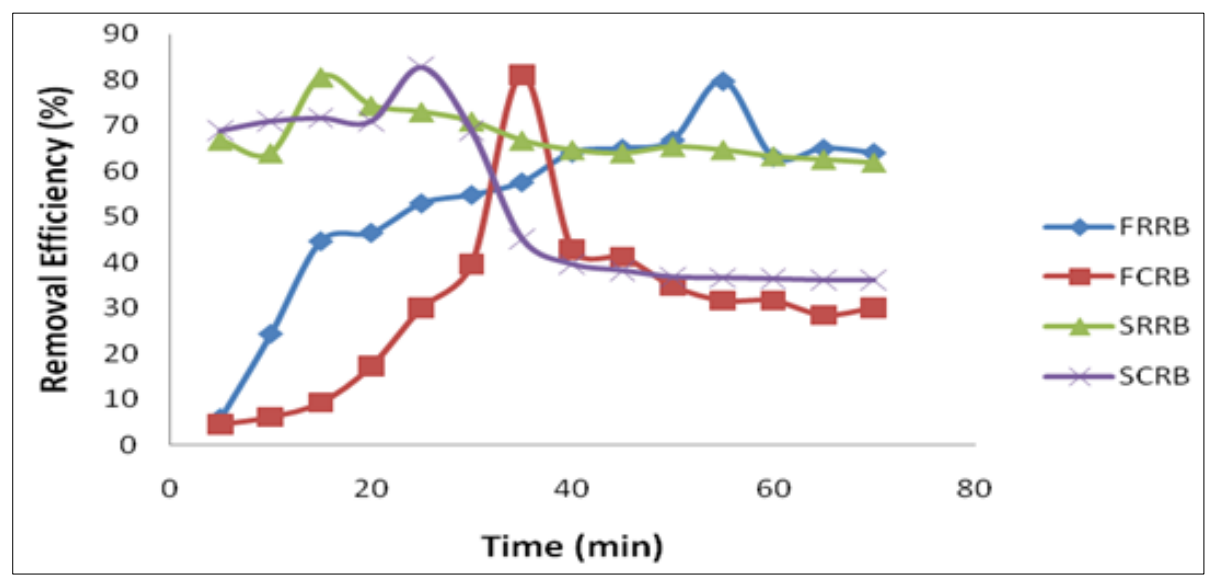

Figure 6. Contact time effect on biosorptive elimination of fluoride and sulfide ions; $10 \mathrm{ppm}$ fluoride ions, $20 \mathrm{mg} / \mathrm{L}$ sulfide ions, both solutions in $50 \mathrm{~mL}$ volume; RRB, CRB 0.1-2.0g; time 5-70 min; shaking speed 50-450 rpm; $p \mathrm{H} 3-9$; temperature $293 \mathrm{~K}$

\section{(c) Effect of Agitation Speed}

It is shown Figure 7 that the maximum biosorption for CRB was $82.25 \%$ of sulfide ions at $200 \mathrm{rpm}$ (SCRB curve), while CRB also showed $79.44 \%$ of fluoride ions biosorptive removal at $250 \mathrm{rpm}$ (FCRB curve). In adsorption process, the agitation rate is an important parameter, as it effects the adsorbate distribution in the solution and the construction of the outer boundary film. The increase in agitation speed results in more turbulence and energy dissipation in the mixing zone, which decrease the boundary layer resistance and boundary film thickness. These facts increase the adsorption capacity at the early stages.

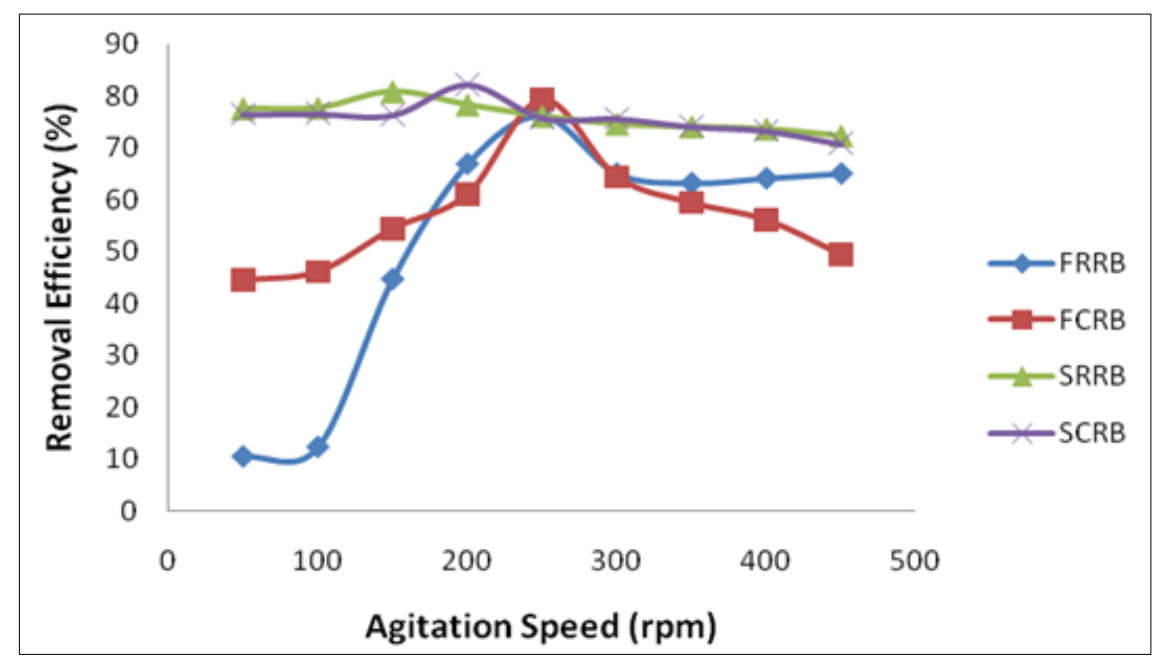

Figure 7. Agitation speed effect on biosorptive elimination of fluoride and sulfide ions; $10 \mathrm{ppm}$ fluoride ions, $20 \mathrm{mg} / \mathrm{L}$ sulfide ions, both solutions in $50 \mathrm{~mL}$ volume; RRB, CRB 0.1-2.0 g; time 5-70 min; shaking speed 50-450 rpm; $p \mathrm{H} 3-9$; temperature $293 \mathrm{~K}$

\section{(d) Effect of $p \mathbf{H}$}

It is considered as the most important parameter that affects the adsorption process. This parameter affects the degree of ionization of the adsorbate in the solution, the surface charge of the adsorbent and the division of functional groups on the active sites of the adsorbent. The effect of $p \mathrm{H}$ on removal 
efficiency is shown in Figure 8. CRB showed maximum removal efficiency $79 \%$ of fluoride ions (FCRB curve), at lower $p \mathrm{H}=5$ which was possibly due to the rise in electrostatic attraction between positively charged functional groups and negatively charged anions molecule.

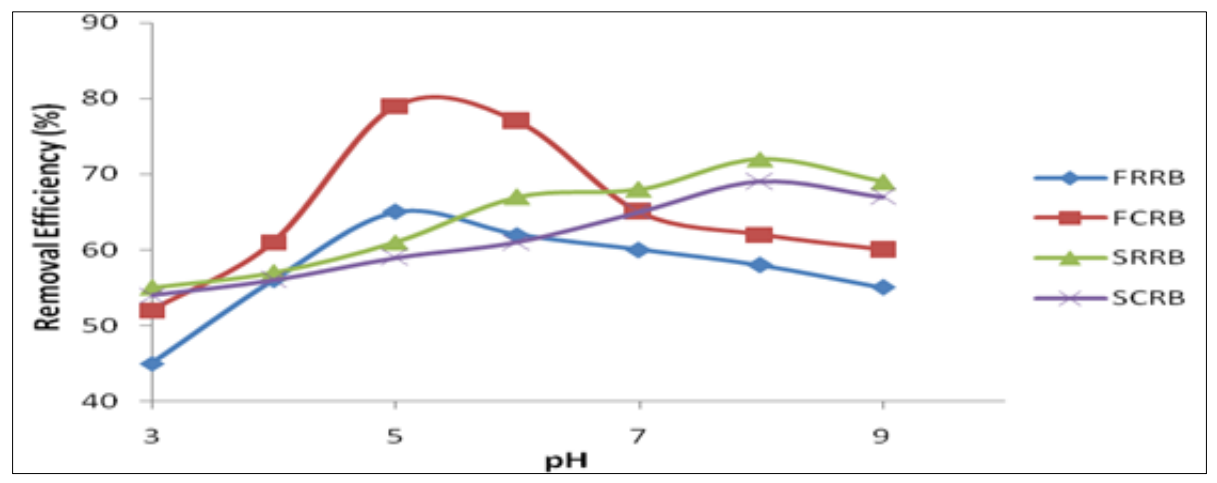

Figure 8. Waste water solution $p \mathrm{H}$ effect on biosorptive elimination of fluoride and sulfide ions; $10 \mathrm{ppm}$ fluoride ions, $20 \mathrm{mg} / \mathrm{L}$ sulfide ions, both solutions in $50 \mathrm{~mL}$ volume; RRB, CRB 0.1-2.0 g; time 5-70 min; shaking speed 50-450 rpm; $p \mathrm{H} 3-9$; temperature 293K

\section{(e) Adsorption Isotherms}

The adsorption isotherms are important from both practical and theoretical point of views. The Langmuir isotherm describes monolayer biosorptive removal of contaminants occurred by biosorbents having heterogeneously distributed chelating binding sites on their surfaces [39]. The correlation coefficients and values of parameters obtained from the adsorption of fluoride and sulfide ions on RRB and CRB are given in Table 3. It was revealed that data for adsorption of sulfide and fluoride onto raw and treated rice bran gave a good fit to the Langmuir adsorption isotherm thereby favoring the monolayer chelation mode of biosorption. Values of the regression coefficient also showed the better fit to monolayer adsorption. In case of zinc chloride treated rice bran the adsorption capacity increased for both the sulfide and fluoride. It means that increased roughness on the adsorbents surface provided more surface area for the adsorption of these adsorbates.

Table 3. A comparison of various parameters of different isotherm models

\begin{tabular}{|c|c|c|c|}
\hline \multicolumn{2}{|c|}{ Adsorbent } & \multicolumn{2}{|c|}{ Isotherm's parameters } \\
\hline Pure & $\begin{array}{l}\text { For fluoride or sulfide } \\
\text { adsorption }\end{array}$ & Langmuir & Freundlich \\
\hline \multirow[t]{2}{*}{ RRB } & FRRB & $\begin{array}{l}\mathrm{R}^{2}=0.994 \\
\mathrm{q}_{\mathrm{m}}=1.37 \mathrm{mg} / \mathrm{g} \\
\mathrm{b}=0.03 \mathrm{~L} / \mathrm{g}\end{array}$ & $\begin{array}{l}\mathrm{R}^{2}=0.990 \\
\mathrm{n}=0.93 \\
\mathrm{~K}_{\mathrm{F}}=0.082(\mathrm{~L} / \mathrm{g})^{1-\mathrm{n}}\end{array}$ \\
\hline & SRRB & $\begin{array}{l}\mathrm{R}^{2}=0.99 \\
\mathrm{q}_{\mathrm{m}}=3.79 \mathrm{mg} / \mathrm{g} \\
\mathrm{b}=0.099 \mathrm{~L} / \mathrm{g}\end{array}$ & $\begin{array}{l}\mathrm{R}^{2}=0.99 \\
\mathrm{n}=1.10 \\
\mathrm{~K}_{\mathrm{F}}=0.33(\mathrm{~L} / \mathrm{g})^{1-\mathrm{n}}\end{array}$ \\
\hline \multirow[t]{2}{*}{ CRB } & FCRB & $\begin{array}{l}\mathrm{R}^{2}=0.992 \\
\mathrm{q}_{\mathrm{m}}=2.06 \mathrm{mg} / \mathrm{g} \\
\mathrm{b}=0.03 \mathrm{~L} / \mathrm{g}\end{array}$ & $\begin{array}{l}\mathrm{R}^{2}=0.987 \\
\mathrm{n}=0.98 \\
\mathrm{~K}_{\mathrm{F}}=0.050(\mathrm{~L} / \mathrm{g})^{1-\mathrm{n}}\end{array}$ \\
\hline & SCRB & $\begin{array}{l}\mathrm{R}^{2}=0.993 \\
\mathrm{q}_{\mathrm{m}}=7.08 \mathrm{mg} / \mathrm{g} \\
\mathrm{b}=0.013 \mathrm{~L} / \mathrm{g}\end{array}$ & $\begin{array}{l}\mathrm{R}^{2}=0.974 \\
\mathrm{n}=1.03 \\
\mathrm{~K}_{\mathrm{F}}=0.089(\mathrm{~L} / \mathrm{g})^{1-\mathrm{n}}\end{array}$ \\
\hline
\end{tabular}

\section{Conclusions}

Adsorption of sulfide and fluoride onto rice bran during the present study revealed that better adsorption of fluoride occurred in slightly acidic medium whereas sulfide showed good adsorption in basic medium. Relatively lesser adsorbent dose was required after the treatment with zinc chloride in both the cases. Isothermal study revealed that adsorption of sulfide and fluoride onto chemically 
modified rice bran followed Langmuir adsorption isotherm and does not fit the Freundlich isotherm well. From the present work, it was concluded that zinc chloride treated rice bran is the good alternate of raw rice bran for the efficient removal of sulfide and fluoride.

Acknowledgment.We are thankful to home institute for funding this project.

\section{References}

1.SUDHA, R., KALPANA, K., RAJACHANDRASEKAR, T., ARIVOLI, S., J.Chemistry, 4, 2007, p. 238

2.***World Health Organization, Guidelines for Drinking-water Quality. First Addendum to the $4^{\text {th }}$ edition, 2017

3. ARORA, H., CHATTOPADHYA, S., Ind.J.Environ.Health, 16, 1974, p. 140

4. FAN, C.S., LI, K.C., J.Cleaner Prod., 57, 2013, p. 335

5. PONSOT, I., FALCONE, R., BERNARDO, E., Ceramics Int., 39, 2013, p. 6907

6. SHEN, F., CHEN, X., GAO, P., CHEN, G., Chem.Eng.Sci., 58, 2003, p. 987

7.DROUICHE, N., DJOUADI-BELKADA, F., OUSLIMANE, T., KEFAIFI, A., FATHI, J., AHMETOVIC, E., Desal.Water Treat., 51, 2013, p. 5965

8. DAR, A., SHAFIQUE, U., ANWAR, J., ALI MUNAWAR, M., J.Sulfur Chem., 36, 2015, p. 187

9. EDWARDS, S., ALHARTHI, R., GHALY, A.E., Amer.J.Environ.Sci., 7, 2011, p. 295

10. VALEIKA, V., BELESKA, K., VALEIKIENE, V., Polish J.Environ.Stud., 15, 2006, p. 623

11.DROUICHE, N., AOUDJ, S., HECINI, M., GHAFFOUR, N., LOUNICI, H., MAMERI, N., J.Hazard.Mat., 169, 2009, p. 65

12.RAO, N.M., BHASKARAN, C., J.Fluor.Chem., 41, 1988, p. 17

13.TAHAIKT, M., EL HABBANI, R., HADDOU, A.A., ACHARY, I., AMOR, Z., TAKY, M., ALAMI, A., BOUGHRIBA, A., HAFSI, M., ELMIDAOUI, A., Desalination, 212, 2007, p. 46

14.AMOR, Z., BARIOU, B., MAMERI, N., TAKY, M., NICOLAS, S., ELMIDAOUI, A., Desalination, 133, 2001, p. 215

15.AMOR, Z., MALKI, S., TAKY, M., BARIOU, B., MAMERI, N., ELMIDAOUI, A., Desalination, 120, 1998, p. 263

16. TEMBHURKAR, A., DONGRE, S., J.Environ.Sci.Engin., 48, 2006, p. 151

17. FAN, X., PARKER, D.J., SMITH, M.D., Water Research, 37, 2003, p. 4929

18. MURUGANANTHAN, M., RAJU, G.B., PRABHAKAR, S., J.Hazard.Mat., 109, 2004,p. 37

19. MILlERO, F.J., LEFERRIERE, A., FERNANDEZ, M., HUBINGER, S., HERSHEY, J., Environ.Sci.Technol., 23, 1989, p. 209

20. FOSSO-KANKEU, E., MULABA-BAFUBIANDI, A., Phys.Chem.Earth, Parts A/B/C, 67, 2014, p. 242

21. JAIN, C.K., MALIK, D.S., YADAV, A.K., Environ.Processes, 3, 2016, p. 495

22. XU, X., GAO, B., JIN, B., YUE, Q., J.Mol.Liquids, 215, 2016, p. 565

23. HAGGERTY, G.M., BOWMAN, R.S., Environ.Sci.Technol., 28, 1994, p. 452

24. TIAN, Y., WU, M., LIU, R., WANG, D., LIN, X., LIU, W., MA, L., LI, Y., HUANG, Y., J.Hazard.Mat., 185, 2011, p. 93

25. KAMBLE, S.P., DIXIT, P., RAYALU, S.S., LABHSETWAR, N.K., Desalination, 249, 2009, p. 687

26. DAIFULLAH, A., YAKOUT, S., ELREEFY, S., J.Hazard.Mat., 147, 2007, p. 633

27. SIVASANKAR, V., RAJKUMAR, S., MURUGESH, S., DARCHEN, A., J.Hazard.Mat., 225, 2012, p. 164

28. KHAN, M.A., AHN, Y.T., KUMAR, M., LEE, W., MIN, B., KIM, G., CHO, D.W., PARK, W.B., JEON, B.H., Separation Sci.Technol., 46, 2011, p. 2575

29. NAMASIVAYAM, C., SANGEETHA, D., Desalination, 219, 2008, p. 1

30. NAMASIVAYAM, C., PRATHAP, K., Environ.Technol., 27, 2006, p. 923 
31. OZKUTUK, E.B., ÖZALP, E., OZCAN, A.A., DILTEMIZ, S.E., Hacettepe J.Biol.Chem., 37, 2009, p. 207

32. NAMASIVAYAM, C., SANGEETHA, D., Chemosphere, 60, 2005, p. 1616

33. ANIRUDHAN, T.S., SUCHITHRA, P., Indian J.Chem.Technol., 17, 2010, p. 247

34. ITODO, A., ABDUlRAhMAN, F., HASSAN, L., MAIGANDI, S., ITODO, H., New York Sci.J., 3, 2010, p. 17

35. RAHMAN, N.N.N.A., SHAHADAT, M., WON, C.A., OMAR, F.M., RSC Advances, 4, 2014, p. 58156

36. HENECZKOWSKI, M., KOPACZ, M., NOWAK, D., KUZNIAR, A., Acta Polon.Pharm. Drug Res., 58, 2001, p. 415

37. PAVIA, D.L, LAMPMAN, G.M, KRIZ, G.S., VYVYAN, J.R., Introduction to

Spectroscopy, $4^{\text {th }}$ edition, Brooks/Cole, CENCAGE Learning, Belmont CA, 2009

38. FENG, W., KWON, S., BORGUET, E., VIDIC, R., Environ.Sci.Technol., 39, 2005, p. 9744

39. HO, Y.S., WANG, C.C., Process Biochem., 39, 2004, p. 761

\section{List of Abbreviations:}

$\mathrm{RRB}=$ Raw rice bran

$\mathrm{CRB}=$ Chemical treated rice bran

FRRB = Fluoride biosorption on Raw rice bran

FCRB = Fluoride biosorption on Chemical treated rice bran

SRRB $=$ Sulfide biosorption on Raw rice bran

$\mathrm{SCRB}=$ Sulfide biosorption on Chemical treated rice bran

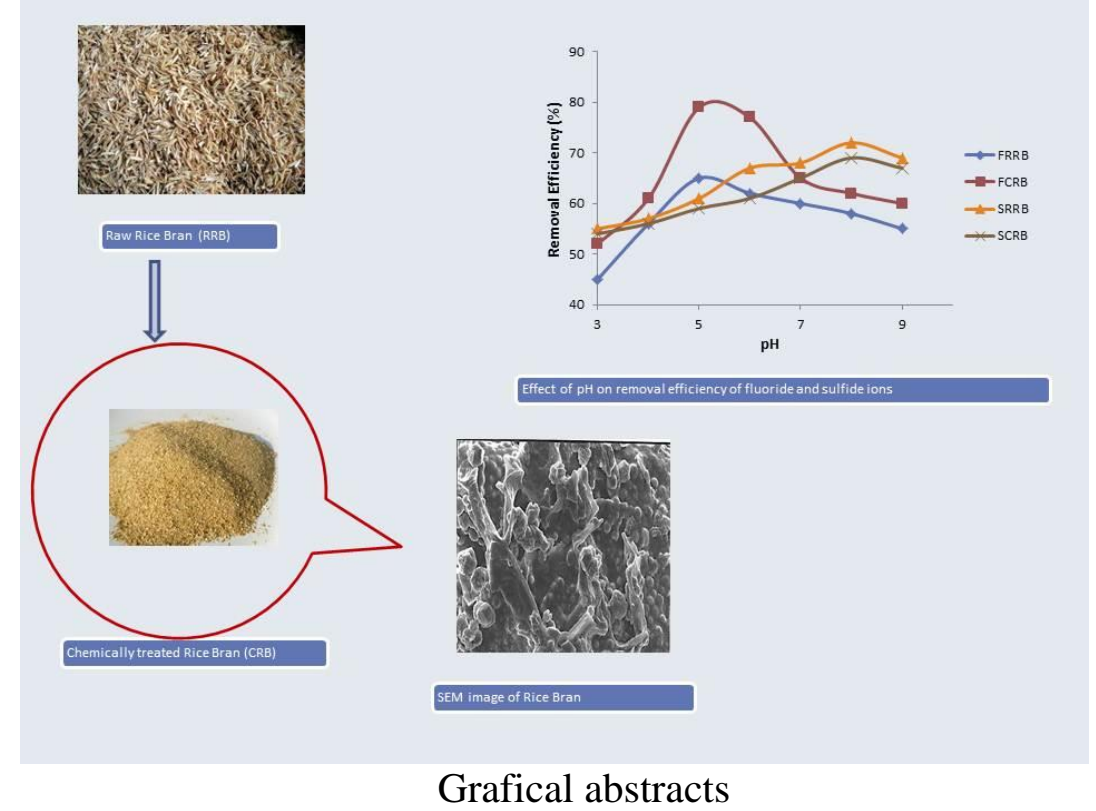

\section{Highlights}

-Removal of fluoride and sulfide anionic species was investigated in this work by rice bran.

-Adsorption capacity of rice bran was enhanced by chemical treatment with $\mathrm{ZnCl}_{2}$.

-Structural changes were monitored by FT-IR and SEM micrographs.

-Fluoride and Sulfide were examined spectrophotometrically in samples and effective removal was observed. 